\title{
The taxonomy, biogeography and conservation of the myrmecophilous Chrysoritis butterflies (Lepidoptera: Lycaenidae) in South Africa
}

\author{
R.F. TERblanche and H. VAN HAMbURG
}

Terblanche, R.F. and H. Van Hamburg. 2003. The taxonomy, biogeography and conservation of the myrmecophilous Chrysoritis butterflies (Lepidoptera: Lycaenidae) in South Africa. Koedoe 46(2): 65-81. Pretoria. ISSN 0075-6458.

The relevance and integration of scientific knowledge to conservation management of the locally popular and highly endemic butterfly genus Chrysoritis are investigated within the research fields of taxonomy and biogeography. The butterfly genus Chrysoritis contains at least 41 species endemic to South Africa. The taxonomy of Chrysoritis has reached a state where revisions could easily result in a plethora of names between "lumping and splitting". In practice, the state of the taxonomy of these butterflies on species level may alter their conservation priority. The two most species rich species groups in Chrysoritis have different centres of endemism, however, a butterfly atlas becomes a necessity to reveal more about their biogeography. There is an absence of butterfly species lists in many of our National Parks and Nature Reserves. Legislation should facilitate rather than limit the valuable role of the amateur lepidopterist to add distribution records. In turn, the amateur lepidopterists should adapt and make an effort to explore unknown localities, apart from monitoring butterflies at their well-known localities. The red listing of localised butterflies in South Africa, including a number of Chrysoritis species, is in need of an urgent review in the light of the most recent IUCN categories. A species such as Chrysoritis dicksoni should be protected by law - but at its known localities. The scenario that real conservation action is only needed if the last known locality of a butterfly is threatened, should be abolished. A paradigm shift to conserve the metapopulations of the highly endemic Chrysoritis genus and not merely a few of its species as items that appear on lists, seems necessary.

Key words: Chrysoritis, myrmecophilous, endemic, conservation, research priorities, environmental management, South Africa, taxonomy, biogeography, red list

R.F. Terblanche and H. Van Hamburg, School of Environmental Sciences and Development, Private Bag X6001, Potchefstroom University for CHE, Potchefstroom, 2520 South Africa.

\section{Introduction}

The purpose of this paper is to consider the conservation of the genus Chrysoritis as a real example of insect conservation in South Africa. Interactions between disciplines, such as taxonomy and legislation, as well as the role of various interested parties such as the amateur Lepidopterists and professionals, have been poorly investigated to date. The main objective of this overview is to identify research needs and to create a framework along which research priorities could be directed towards sustainable environmental management with a view to butterfly conservation. All the members of the genus
Chrysoritis seem to be myrmecophilous (Heath 1997a; 2001). Myrmecophilous butterflies pose special challenges for conservation management due to their intricate habitat requirements and populations are often localised.

A summary of the distribution of the Chrysoritis species in Lesotho, Swaziland and the provinces of South Africa is presented for the first time (Table 1). Biogeographic notes with regard to Chrysoritis is given from a regional perspective on conservation priorities and will hopefully stimulate further research on the distribution of these butterflies. 


\section{Table 1}

The distribution of Chrysoritis species in the provinces of South Africa as well as the Kingdom of Lesotho and Swaziland. A number 1 indicates that the Chrysoritis species occurs in that area. The major regional literature sources used were Clark \& Dickson (1971), Terblanche (1991), Keller, Amodio \& Stänz (1997),

Kloppers \& Van Son (1978), Pringle, Henning \& Ball (1994), Duke, Saunders \& Saunders (1999), and Claassens (2000).

Chrysoritis Species Lesotho, Swaziland and Provinces of South Africa EC FS GP KZ LE LI MP $\mathrm{NC}$ NW

\section{Chrysaor Species Group}

Chrysoritis aethon (Trimen \& Bowker, 1887)

Chrysoritis aureus (Van Son, 1966)

Chrysoritis chrysaor (Trimen, 1864)

Chrysoritis lycegenes (Trimen, 1874)

Chrysoritis lyncurium (Trimen, 1868)

Chrysoritis midas (Pennington, 1962)

Chrysoritis natalensis (Van Son, 1966)

Chrysoritis phosphor (Trimen, 1866)

$\begin{array}{lll}1 & 1 & \\ & 1 & \\ 1 & & \\ & & \\ 1 & & \\ 1 & & \end{array}$

\section{Chrysantas Species Group}

Chrysoritis chrysantas (Trimen, 1868)

\section{Oreas Species Group}

Chrysoritis dicksoni (Gabriel, 1946)

Chrysoritis oreas (Trimen, 1891)

1

$\begin{array}{ll}1 & \\ 1 & \\ 1 & 1 \\ & \\ 1 & \end{array}$

\section{Zeuxo Species Group}

Chrysoritis zeuxo (Linnaeus, 1764)

Chrysoritis zonarius (Riley, 1938)

\section{Pyroeis Species Group}

Chrysoritis felthami (Trimen, 1904)

Chrysoritis pyroeis (Trimen, 1864)

\section{Thysbe Species Group}

Chrysoritis adonis (Pennington, 1962)

Chrysoritis aridus (Pennington, 1953)

Chrysoritis azurius (Swanepoel, 1975)

Chrysoritis beaufortius (Dickson, 1966)

Chrysoritis beulah (Quickelberge, 1966)

Chrysoritis blencathrae (Heath and Ball, 1992)

Chrysoritis braueri (Pennington, 1967)

Chrysoritis brooksi (Riley, 1938)

Chrysoritis daphne (Dickson, 1975)

Chrysoritis endymion (Pennington, 1962)

Chrysoritis irene (Pennington, 1968)

Chrysoritis nigricans (Aurivillius, 1924)

Chrysoritis orientalis (Swanepoel, 1976)

Chrysoritis palmus subsp. palmus (Stoll, 1781)

Chrysoritis pan (Pennington, 1962)

Chrysoritis pelion (Pennington, 1953)

Chrysoritis penningtoni (Riley, 1938)

Chrysoritis perseus (Henning, 1977)

Chrysoritis plutus (Pennington, 1976)

Chrysoritis pyramus (Pennington, 1953)

Chrysoritis rileyi (Dickson, 1966)

Chrysoritis swanepoeli (Dickson, 1965)

Chrysoritis thysbe (Linnaeus, 1764)

Chrysoritis trimeni (Riley, 1938)

Chrysoritis turneri (Riley, 1938)

Chrysoritis uranus (Pennington, 1962)

Chrysoritis violescens (Dickson, 1971)

\begin{tabular}{lccccccccccc}
\hline & EC & FS & GP & KZ & LE & LI & MP & NC & NW & WC & SW \\
TOTAL & 13 & 3 & 1 & 9 & 2 & 0 & 5 & 14 & 0 & 25 & 1 \\
\hline
\end{tabular}




\section{Discussion}

\section{Taxonomy of the genus Chrysoritis}

Most of the present Chrysoritis species were previously known as the Poecilmitis species. Based on wing pattern, genitalia features and larval morphology, Heath (1997a) treated the genera Chrysoritis, Poecilmitis, Bowkeria and Oxychaeta as synonyms of Chrysoritis. His treatment with regard to Chrysoritis, Poecilmitis and Oxychaeta was supported by the phylogeny inferred from mitochondrial cytochrome oxidase I sequences (Rand et al. 2000). Rand et al. (2000) could not ascertain the phylogenetic position of Bowkeria due to a lack of fresh specimens, being a rare canopy dweller and difficult to obtain. The inclusion of Bowkeria in Chrysoritis needs further study, especially since its life history remains unknown. The studies of Heath (1997a) that led to the inclusion of Chrysoritis, Oxychaeta and Poecilmitis being synonyms of Chrysoritis, as well as Rand et al. (2000) expanded the understanding of the genus Chrysoritis considerably, including the ecological functional similarities among the species in this group. For instance, apart from Chrysoritis dicksoni (previously known as Oxychaeta dicksoni) that might have a derived aphytophagy, the rest of the Chrysoritis species studied to date are phytophagous with a mutualism that includes myrmicine ants of the genera Myrmicaria and Crematogaster.

Figure 1 illustrates some members of the species groups of Chrysoritis. Heath (2001) is followed for the species groups within the Chrysoritis genus, which in turn is largely based on Heath (1997a) and Rand et al. (2000) (see Table 1 for the species and species groups). Heath (2001) instated a number of synonymies within the genus Chrysoritis, which reduced the total number of species from 59 to 42 . It was suggested that there may be a number of synonymies among the remaining 42 species as well. Even if the number of species was to be lowered further, the number of endemic species of this genus could still be regarded as very high. Although the latest synonymies presented by Heath (2001) have been followed in this paper and in the most recent checklist of Southern African butterflies (Vári et al. 2002), there is currently much debate among Lepidopterists of Africa whether all the synonymies suggested by Heath (2001) should be accepted. A few factors that could have
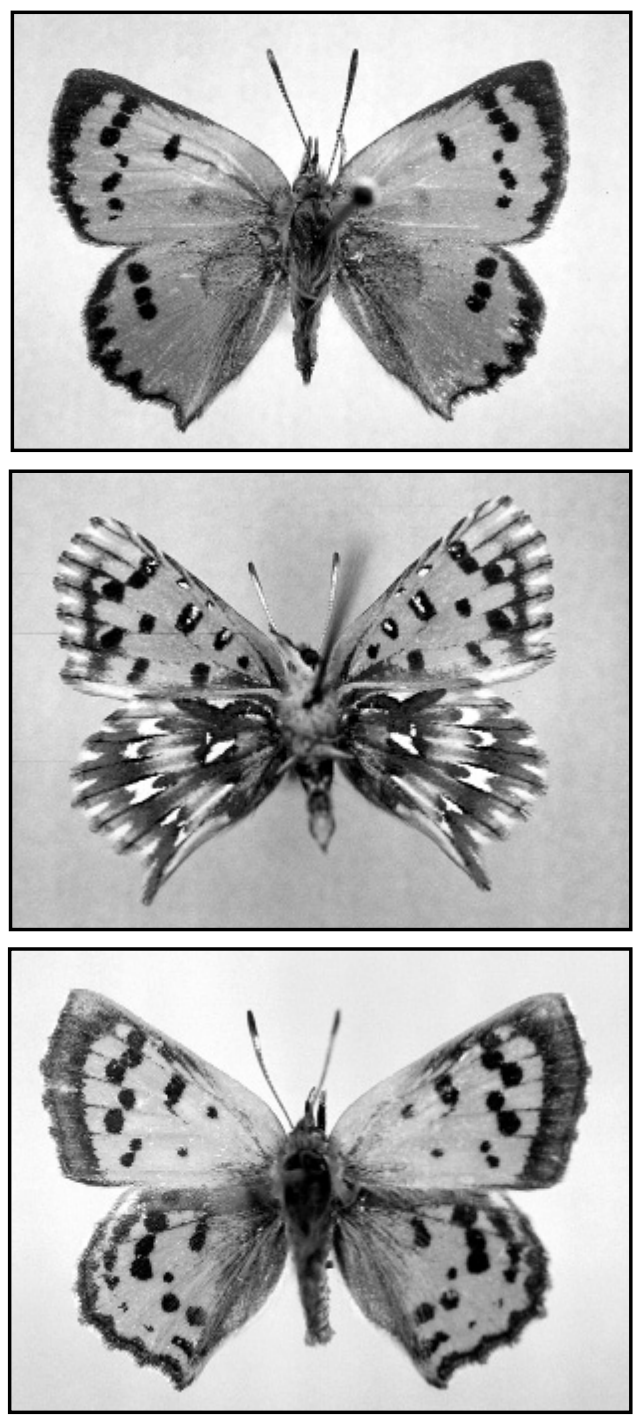

Fig. 1. Examples of Chrysoritis species. Top: C. aethon; Middle: C. pelion; Bottom: C. zeuxo. 
led to the confusion in Lepidopterists' circles are briefly discussed below.

Heath (2001) stated that his conclusions rely in part on the paper by Rand et al. (2000) and a revision of Aphnaeini (Heath 1997a) but did not specify to what extent for each of the synonymies. Rand et al. (2000) investigated mitochondrial DNA sequences of only 19 species of the former 59 species of Chrysoritis species. Although this investigation was to a great extent sufficient to clarify and confirm the species groups and other phylogenetic relationships within the genus Chrysoritis, not enough information was gained to base synonymies of species on, with the possible exception of the Chrysoritis zeuxo species group which is the only group of Chrysoritis of which some DNA information exists for all the species in the group. It seems that the synonymies presented by Heath (2001) of most of the Chrysoritis species are still largely based on morphological and life history information and not the DNA study by Rand et al. (2000).

Heath (1997a, 1997b) showed that the morphology of Chrysoritis genitalia, even among the majority of the species in the genus, is very uniform in structure, and that this might be related to their myrmecophily. Therefore, the separation of Chrysoritis species relies on other morphological characteristics. Unfortunately, other morphological details and life history information that were presented to sink species in the Heath paper (2001), were not presented or illustrated in any specific detail for any of the synonymies. Reference to characterisics specified in the original descriptions as well as the type series of all the entities that were synonomised, were lacking at large. Heath (2001) states that rearing Chrysoritis over several years from egg to adult from caterpillars collected in the field from various localities, has demonstrated the extent to which the environment could, during the larval stage, affect adult wing shape, size and the markings of both wing surfaces. No reference to controlled experiments in a climatic breeding room, were provided. Therefore, in the comparisons of the life histories, the reader could not confirm or repeat the judgements. One example, Chrysoritis lycia, has been synonimised with Chrysoritis chrysaor. Based on breeding experiments, of which no further details apart from the host plants and localities are presented, the conclusion is drawn that Chrysoritis lycia could be considered an extreme and more yellowish form of Chrysoritis chrysaor. However, important other morphological characteristics used to distinguish Chrysoritis lycia from Chrysoritis chrysaor, such as the series of markings on the hind wing underside margins are not discussed. The Chrysoritis lycia material has also been bred from material at Leipoldtville, which is a few hundred kilometres from the type locality near Matjesfontein. Even if the synonymies and Heaths' judgements based on his reference collection were correct in these cases, the above lack of details, illustrations as well as more specific details about the material and methods could have led to the present confusion. It is to be questioned if sufficient information is available to synonimise many of the Chrysoritis species at present. A similar analogy exists in the plant genus Haworthia that also contains variations between and within populations and which is also of considerable amateur and collectors' interest (see Terblanche et al. 1993; Bayer 1999).

Heath (2001) suggested that other synonymies might be extant among more Chrysoritis species, especially within the Chrysoritis chrysaor species group. This follows the suggestion by Owen-Johnston (1991) that Chrysoritis lycegenes and Chrysoritis lyncurium and an unidentified Chrysoritis entity that occurs at Morgenzon in southern Mpumalanga, might be a cline belonging to the same species (Owen-Johnston 1991). In addtion Heath (2001) suggested that the relation between Chrysoritis aethon and Chrysoritis aureus should be investigated. The habitats of Chrysoritis lyncurium seem to be in great danger, especially from alien invasion (Woodhall 1996). This may butterfly escape as a conservation priority due to taxonomic uncertainties. 
Table 2

A summary of the red data book status of Chrysoritis species in the past. Literature sources: S.F. \& G.A. Henning (1989) and G.A \& S.F. Henning (1995). The taxonomic status and taxonomic research recommendations according to Heath (2001) are given in the last column.

Species Group and Species $\quad$ Red Data Status Proposed Taxonomic Status

19891995 Taxonomic status (Heath, 2001)

\section{Chrysaor species group}

Chrysoritis aureus (Trimen, 1864)

Chrysoritis lyncurium (Trimen, 1868)

Chrysoritis phosphor subsp. borealis

(Quickelberge, 1972)

\section{Oreas Species Group}

Chrysoritis dicksoni (Gabriel, 1946)

Chrysoritis oreas (Trimen, 1891)

\section{Zeuxo Species Group}

Chrysoritis cottrelli (Dickson, 1975)

\section{Pyroeis Species Group}

Chrysoritis pyroeis subsp. hersaleki

(Dickson, 1970)

\section{Thysbe Species Group}

Chrysoritis adonis (Pennington, 1962)

Chrysoritis azurius (Swanepoel, 1975)

Chrysoritis balli

(Dickson \& G.A. Henning, 1980)

Chrysoritis brooksi subsp. taerei

(Dickson, 1966)

Chrysoritis daphne (Dickson, 1975)

Chrysoritis endymion (Pennington, 1962)

Chrysoritis irene (Pennington, 1968)

Chrysoritis henningi (Bampton, 1981)

Chrysoritis hyperion(Dickson, 1975)

Chrysoritis kaplani (S.F. Henning, 1980)

Chrysoritis lyndseyae (S.F. Henning, 1979)

Chrysoritis mithras (Pringle, 1995)

Chrysoritis nigricans subsp. nigricans

(Aurivillius, 1924)

Chrysoritis nigricans subsp. zwartbergae

(Dickson, 1982)

Chrysoritis orientalis (Swanepoel, 1976)

Chrysoritis pan (Pennington, 1962)

Chrysoritis penningtoni (Riley, 1938)

Chrysoritis pyramus (Pennington, 1953)

Chrysoritis rileyi (Dickson, 1966)

Chrysoritis stepheni (Dickson, 1978

Chrysoritis swanepoeli (Dickson, 1965)

Chrysoritis trimeni (Riley, 1938)

Chrysoritis wykehami (Dickson, 1980)

$\begin{array}{lll}\mathrm{R} & \mathrm{R} & \text { Relation with } C \text {. aethon needs research } \\ \mathrm{R} & \mathrm{R} & \text { Relation with } C \text {. lycegenes needs research } \\ \mathrm{R} & \mathrm{R} & \text { Status quo }\end{array}$

V E Status quo

R R Status quo

E $\quad \mathrm{R} \quad$ Regarded as a synonym of C. zeuxo

R $\quad \mathrm{R} \quad$ Status quo

$\begin{array}{lll}\text { R } & \text { I } & \text { Status quo } \\ \text { R } & \text { I } & \text { Status quo } \\ \text { R } & \text { I } & \text { Synomym } \\ & & \\ \text { R } & \text { I } & \text { Status quo }\end{array}$

R I Relation with C. swanepoeli needs research

$\mathrm{R} \quad \mathrm{I}$ Status quo

$\mathrm{R} \quad \mathrm{R} \quad$ Status quo

R $\quad \mathrm{R} \quad$ Regarded as a synonym of $C$. pan

$\mathrm{R} \quad \mathrm{I} \quad$ Regarded as a synonym of $C$. swanepoeli

$\mathrm{R} \quad \mathrm{R} \quad$ Regarded as a synonym of $C$. beaufortius

I I Regarded as synonym of $C$. thysbe subsp. bamptoni

- $\quad$ R Regarded a subsp. of C. thysbe by Heath (2001)

I I Status quo

I I Status quo

I I Relation with C. pelion needs research

I I Contains several new synonymies

$\mathrm{R}$ I Status quo

$\mathrm{R} \quad \mathrm{I} \quad$ Contains $C$. balli as a new synonymy. Relation with

C. thysbe needs research

R I Status quo

$\mathrm{R} \quad \mathrm{I} \quad$ Regarded as synonym of $C$. beaufortius

$\mathrm{R} \quad \mathrm{I} \quad$ Contains $C$. hyperion as a new synonymy.

Relation with $C$. daphne needs research

Relation with C. pan needs research

Regarded as a synonym of $C$. turneri

by Heath (2001)

$\mathrm{R}=$ Rare $; \mathrm{V}=$ Vulnerable $; \mathrm{E}=$ Endangered; $\mathrm{I}=$ Indeterminate 
The taxonomic uncertainties regarding the Chrysoritis species are of much more than academic importance, since the conservation of unique entities are at stake. For instance, most often a species has a higher priority in practice as a conservation priority than a subspecies or a form that is part of a "cline". Furthermore, species and subspecies appear on the protected or red lists and not unique habitats. More specifically, it means that the conservation priority for entities such as Chrysoritis hyperion, Chrysoritis lyndseyae, Chrysoritis kaplani and Chrysoritis stepheni, which were all regarded as rare or intermediate in the red data book of Henning \& Henning (1989), could change considerably (see Table 2). To name one more example: Chrysoritis cottrelli was previously regarded as endangered (1989) but may dissapear from the revised list (Table 2). These species are now all regarded as synonyms of other species according to Heath (2001). A taxonomic impediment could lead directly to a conservation impediment (New 1997).

The above illustrates the importance of taxonomy and its implications for conservation of these localised butterfly species. However, it is perhaps the perception of conservation of rare butterflies that must change. The genus Chrysoritis in its entirety is highly endemic and contains a large number of populations and subpopulations of which most are very localised (even for some of the more widespread species). One is also struck by the variability within and among the local (sub) populations of Chrysoritis species. With regard to wing pattern and wing morphology, some of them are seemingly on their way to become species, and other forms/entities perhaps becoming less plentiful - these life processes should be conserved. It is especially the mixture of Chrysoritis thysbe forms along the western and southern coast of South Africa as well as the adjacent inland areas, that reflects entities in a stage of speciation difficult to estimate. Sympatry and allopatry have been poorly resolved in Chrysoritis, especially for example along the western coast and the Swartberg. It is often difficult to know whether different populations or variations are encountered. Such localities include Lambert's Bay, Hondeklip Bay, and Port Nolloth along the western coast in the Northern Cape. These localised populations are indicative of unique sets of habitat requirements. A small colony of a widespread Chrysoritis that deserves conservation is the colony of Chrysoritis thysbe at Hout Bay in the Cape Peninsula (Claassens 1994). For insect conservation, the impact of exotic and invasive flora is of particular concern in such rare and restricted habitat types (McGeoch 2002). The butterflies of Chrysoritis with their either metallic orange or metallic orange and blue upper sides of wings could all be regarded as an aesthetic asset and much could be lost before science unravels the full significance of their phylogeny.

\section{Distribution of Chrysoritis species}

Obviously, a better knowledge of the distribution of Chrysoritis species will enhance research (taxonomy and ecology) and the applications of environmental impact assessments and management. Despite many shortcomings in the study of the distribution of butterflies, proportionally far more information is available compared to many other groups of arthropods in Africa. At least one knows to some extent that a butterfly is rare or not - this cannot apply to many other insects of which the information on distribution and the manpower to obtain these are very poor. Furthermore, relatively few butterflies await discovery in South Africa, which is not true for many other insect groups. Despite the possibilities that such a well-known group presents in terms of distribution, it was is not yet been applied sufficiently in the African context. A butterfly atlas is becoming an increasing need to interpret the distribution of South African butterflies (Terblanche \& Taylor 2000).

Table 1 gives a summary of the distribution of all the Chrysoritis species in all the new provinces (since 1994) of South Africa as well as other African countries where these butterflies have been recorded. Political 
boundaries were used due to the lack of data in an atlas format. These political boundaries are used for practical reasons since the distribution in standard reference works on butterflies are commonly described according to provinces (Cotrell 1985). These political boundaries are still useful, since it is known for example that much of the Fynbos biome is confined to the Western Cape as well as smaller parts of the Eastern and Northern Cape and that the most of the Free State consists of grassland (see Rutherford \& Westfall 1994). Furthermore, the list is now available to conservation authorities in the different regions. Much of the knowledge on the distribution of Chrysoritis species has been accumulated by many amateur lepidopterists.

The genus Chrysoritis is almost entirely endemic to South Africa, Lesotho and Swaziland (Table 1). The only Chrysoritis species collected outside the borders of South Africa, Lesotho or Swaziland, is Chrysoritis chrysantas. This was found in the southern parts of Namibia, by Plowes on the Tiras Mountains (Pringle et al. 1994). The genera Chrysoritis and Poecilmitis, which are today only known as one genus, namely Chrysoritis, had been described as Cape Province centred (an area now known as the Eastern Cape, Western Cape and Northern Cape) by Cottrell (1985). It falls into the category of species mainly confined to the old Cape Province (although some have been to a limited extent recorded outside this area. The work of Cottrell (1985) preceeded the synonymies suggested by Heath (2001) and the new provinces in South Africa so that the levels of endemism are briefly reviewed here. From Table 1, containing the species list according to the revision by Heath (2001), it can be seen that the highest number of Chrysoritis species occurs in the Western Cape, namely 25 (59.5\% of the total), followed by the 14 species from the Northern Cape $(33 \%)$ and 13 species of the Eastern Cape (31\%). This echoes Cottrell (1985) that Chrysoritis is Cape-centred. The richest area of rare endemic Lycaenidae is found in the Cape Fold Mountains (Samways 1993), a trend strongly followed by the Chrysoritis species. There is also a high number of local varieties of subpopulations of Chrysoritis species in the sandy (dune) areas of the Western Cape. The extent to which the entities are sympatric and allopatric has not been clarified sufficiently. More distribution records will add to the taxonomic and ecological insights. Some gaps in the distribution of species might be real rather than artificial, warranting subspecific status of a number of "clines".

No Chrysoritis species have yet been reported from the Highlands of Zimbabwe or further northwards in Africa. This contrasts with species of other ant-associated lycaenid genera with high concentrations of endemic species in South Africa, especially the Western Cape (Fynbos). Such genera include Aloeides, Lepidochrysops and even Thestor. The latter has one recorded species from parts of Zimbabwe. A few Aloeides species and many more Lepidochrysops species are also found in Equatorial Africa. These distributions of ant-associated genera are in contrast with the genus Chrysoritis and highlight the high level of endemism of the genus. The distribution of the two most species rich groups, the Chrysoritis chrysaor species group and the Chrysoritis thysbe species group is discussed in more detail to identify further research priorities of the biogeography of the genus.

All the species within the Chrysoritis chrysaor species group (which include Chrysoritis aureus) lack the metallic blue colour on the upper side of the wings. Instead, they only have an orange upper side with black markings and a metallic sheen on the orange background on the upper side of the wings - from which the vernacular/trivial name "copper" originated (Fig. 1). The metallic blue (opal) colouring with orange and black markings are most prominent in most members of the Chrysoritis thysbe group (Fig. 1). This group is largely confined to the Fynbos biome, with a few exceptions. Simplified, the distribution of Chrysoritis species follows a pattern from the southern (Western and Eastern Cape) part of South Africa with northerly extensions to the west- 
ern escarpment to the coast and eastern escarpment to the coast. Chrysoritis is poorly represented in the central grassland plateau. No Chrysoritis species occur in the savanna biome, hence their absence in the North West and Limpopo provinces of South Africa (Table 1; Fig. 2).

The most northern locality record for a species belonging to the Chrysoritis thysbe species group, on the eastern (moister) side of South Africa, is that of Chrysoritis pelion. The northernmost locality records for Chrysoritis pelion is at the Golden Gate Highlands National Park. M.C. Williams discovered the locality (Terblanche 1991). Chrysoritis pelion was also collected by Terblanche, in January 1991, near Sentinel Mountain, where the Drakensberg and Maluti mountains meet. The butterfly is more widespread to the south, in the highlands of Lesotho (Fig. 2). Both the above localities of Chrysoritis pelion are found at an altitude above $2700 \mathrm{~m}$, in areas with rocks and shrubs, among the grasslands. The highlands, northwards of the Golden Gate High- lands National Park and the Sentinel, drop considerably in height above see level (down to a maximum height of $2350 \mathrm{~m}$ ). Chrysoritis pelion represents the northernmost outlier of the Chrysoritis thysbe group on the eastern side of Southern Africa, where the butterfly is found on the Alti Mountain grassland (Granger \& Bredenkamp 1996). Patches of Afromontane vegetation, affiliated to Fynbos, are scattered throughout this grassland (Granger \& Bredenkamp 1996). This distribution of Chrysoritis pelion represents a faunal reflection of extensions of such Fynbos-affiliated vegetation.

In contrast, Chrysoritis aethon of the Chrysoritis chrysaor species group, has been found much further north on Mariepskop (Fig. 2) (Pringle et al. 1994) and represents at present the most northerly distributed Chrysoritis species. Mariepskop is $510 \mathrm{~km}$ NNE of the Golden Gate Highlands National Park. The Chrysoritis chrysaor species group is significant in the sense that it contains the most north-easterly recorded species of the Chrysoritis genus, namely

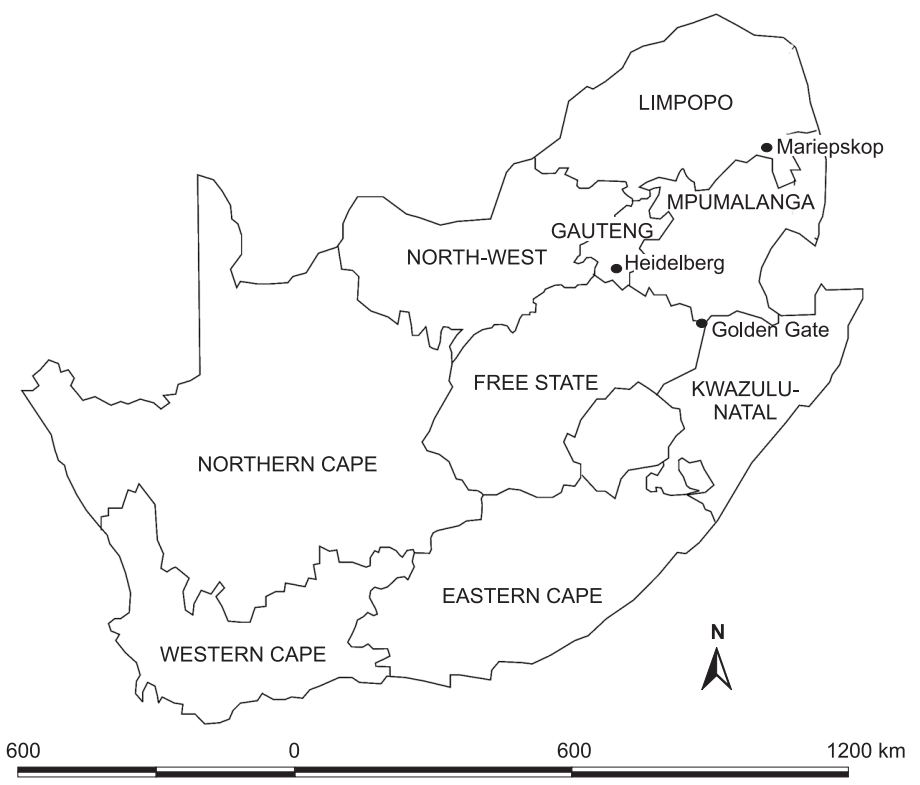

Fig. 2. Map of South Africa showing the nine provinces and three localities of importance. 
Chrysoritis phosphor subsp. phosphor, Chrysoritis aethon, Chrysoritis aureus and the widespread Chrysoritis chrysaor. Significantly, the northern extensions of the genus on the western side of South Africa contain mostly members of the Chrysoritis thysbe group. On the northern extension of their range and on the eastern side of the country, the Chrysoritis chrysaor group is better represented. All the Chrysoritis species that occur in the moister (eastern) side of South Africa belong to the Chrysoritis chrysaor species group and the centre of endemism of the Chrysoritis chrysaor species group seems to be outside the Fynbos biome. Only two of the eight species (that is $25 \%$ ) that belongs to the Chrysoritis chrysaor species group has been recorded in the Western Cape, of which one is also widespread in the eastern side of South Africa. This is in contrast with the tendency of the rest of the genus (Table 1). It seems, therefore, that the centre of endemism of the Chrysoritis chrysaor group is in the highlands of KwaZulu/ Natal (6 species), Mpumalanga (5 species) and the Eastern Cape (4) species. The exception is Chrysoritis natalensis that occurs in the moist, subtropical, eastern coastal areas. Nevertheless, the centre of endemism of the Chrysoritis chrysaor group is not in the Fynbos biome but in the eastern parts of the Grassland biome. Furthermore, when the northerly extensions of the Chrysoritis genus is considered, the Chrysoritis chrysaor group has its centre of endemism within the summer rainfall area, whereas the Chrysoritis thysbe group has its centre of endemism in the winter rainfall area. The only Chrysoritis associated with afromontane forest, namely Chrysoritis phosphor, is also a member of the Chrysoritis chrysaor species group, although Chrysoritis phosphor, that superficially looks atypical to the genus might not be congeneric. Interestingly, Chrysoritis phosphor is often recorded at forest margins bordering grassland. The only Chrysoritis species, apart from the ubiquitous Chrysoritis chrysaor that is encountered sparsely in the Rocky Highveld Grassland, is Chrysoritis aureus. Acocks $(1975,1988)$ interpreted the
Bankenveld (now Rocky Highveld Grassland) as a fire-maintained grassland that would develop into savanna if fire were excluded. Fire, as variable, plays at least an important role in the maintenance of grassland (Bredenkamp \& Van Rooyen 1996; O’Connor \& Bredenkamp 1997). In the light of the above distribution of Chrysoritis species, it is significant that Chrysoritis aureus extends the distribution of Chrysori$t i s$ to inland grassland areas to the west of the escarpment at altitudes between $1600 \mathrm{~m}$ and $1800 \mathrm{~m}$. These distributions show that even among the species groups of Chrysoritis different ecological pressures may have shaped the species.

A study of the vegetation of three localities of Chrysoritis aureus points to the possible importance of fire in maintaining a viable open grassland habitat for the butterfly (Terblanche et al. 2003). Since many colonies of species of the Chrysoritis chrysaor group is often found in grassy areas not far from forests or well-wooded kloofs, fire and climate may have been important in shaping these species and their ant associations.

After decades of exploration by a number of Lepidopterists only five confirmed localities of Chrysoritis aureus were reported (Terblanche et al. 2003). A fortunate contribution towards the conservation of Chrysoritis aureus was the discovery of the locality at the Alice Glockner Nature Reserve (near Heidelberg, Gauteng) in 1998 by P.S. Roos and G.A. Henning (Roos \& Henning 2000). This discovery has increased the conservation priority of the, at that stage, undeveloped Alice Glockner Nature Reserve considerably, since this locality would probably have been destroyed by urbanisation. The future of Chrysorities aureus has been secured by the co-operation between developers, government officials and concerned NGO's such as the Lepidopterists' Society of Africa.

Chrysoritis aureus is very localised in all the areas where it occurs. Most of the individuals in such a colony will for most of the time 
Table 3

The five confirmed and apparantly viable localities of Chrysoritis aureus (Heidelberg Copper butterfly)

\begin{tabular}{lccc}
\hline Locality & Province & Grid reference ${ }^{1}$ & Altitude (m) \\
\hline $\begin{array}{l}\text { Alice Glockner Nature Reserve } \\
8 \mathrm{~km} \text { S Heidelberg }\end{array}$ & Gauteng & $26^{\circ} 34^{\prime} \mathrm{S}, 28^{\circ} 22 \mathrm{E}(2628 \mathrm{CB})$ & 1690 \\
Hill N of Greylingstad & Mpumalanga & $26^{\circ} 44^{\prime} \mathrm{S}, 2^{\circ} 44^{\prime} \mathrm{E}(2628 \mathrm{DA})$ & 1810 \\
Malanskraal locality14 km W Balfour & Mpumalanga & $26^{\circ} 39^{\prime} \mathrm{S}, 28^{\circ} 26^{\prime} \mathrm{E}(2628 \mathrm{CB})$ & 1780 \\
Suikerbosrand Nature Reserve & Gauteng & $2^{\circ} 29^{\prime} \mathrm{S}, 28^{\circ} 18^{\prime} \mathrm{E}(2628 \mathrm{AD})$ & 1720 \\
$\begin{array}{l}\text { Type locality at the South African } \\
\text { National Force premises }\end{array}$ & Gauteng & $26^{\circ} 29^{\prime} \mathrm{S}, 2^{\circ} 21^{\prime} \mathrm{E}(2628 \mathrm{AD})$ & 1600 \\
\hline
\end{tabular}

${ }^{1}$ The grid reference reading is from the north-western corner of each minute by minute square.

fly within an area of $200 \mathrm{~m}^{2}$ to $400 \mathrm{~m}^{2}$. The size of these localities is being measured at present. Migration behaviour is not associated with any of the Chrysoritis species and the populations of every species tend to live in relatively small confined areas. The Chrysoritis populations and sub populations are therefore referred to as colonies in literature. Males of the Chrysoritis aureus seem to choose an outpost (usually some branch of a shrub) from where it controls its small territory, whereas females often wander around within the borders of such a colony. Despite the fact that confinement of Chrysoritis species to its habitats is appreciated by all the lepidopterists experienced with the Chrysoritis butterflies, scientific information on the dispersal of Chrysoritis species is absent. Two single males and two single females of Chrysoritis aureus were recorded by R.F. Terblanche on 1 October 2002 and 23 January 2002 at Suikerbosrand Nature Reserve $10.5 \mathrm{~km} \mathrm{~W}$ and $6.5 \mathrm{~km}$ WSW of the known locality in this reserve. No host plant (Clutia pulchella) occurs near these spots, and only a single specimen that was clearly staying in a small area of not more than $25 \mathrm{~m}^{2}$ was recorded each time. The two males were observed, each in an isolated spot more than $100 \mathrm{~m}$ apart, at Perdekop $\left(26^{\circ} 30^{\prime} \mathrm{S} ; 28^{\circ} 15^{\prime} \mathrm{E}\right)$. They were near the summit, defending their small area in the manner they would do in a normal colony. The females were recorded on separate dates, on the northern aspect below the summit of the hill South of Diepkloof (26 $\left.26^{\circ} \mathrm{S} ; 28^{\circ} 12^{\prime} \mathrm{E}\right)$. All these specimens were recorded at an altitude of 1860-1900 m, which is higher than the normal elevation at which Chrysoritis aureus occurs (see Table 3). The markings of the undersides of these specimens left one in no doubt about the identification. This is the first time that such "isolated" Chrysoritis aureus individuals were reported, which is especially significant in the light of the above-mentioned surveys that the Lepidopterists Society of Southern Africa had done in Suikerbosrand Nature Reserve (Henning 1986a, 1986b, 1987). The full significance of these findings is being further researched but may point to dispersal behaviour.

The above outline of the knowledge on the distribution of Chrysoritis aureus highlights a few important aspects of research and conservation management. The importance of metapopulation studies and the lack of knowledge on the dispersal of Chrysoritis species become clear. Corridors and linkages are important for the conservation of insect diversity (Samways 1993; 1994; Pryke \& Samways 2001) and the possible dispersal behaviour of Chrysoritis should be investigated in more detail. 
Conservation history (NGOs, politics, law, education and environmental management)

Science is vital, but alone cannot curb the decline of the earth's biodiversity (Kohm et al. 2000). Kohm et al. (2000) further state that new partnerships and improved communication should be forged among scientists, managers and policy makers so that conservation science could be available and understandable to all parties. Whitten et al. (2001) that ask if conservation biology is merely another scientific discipline, safely nestled within the confines of academia, is very appropriate for butterfly conservation (and not only the forests of Indonesia that are discussed in the relevant paper). The question is further asked whether conservation is not a mission-concerned with judicial reform, political economy, other people's spatial planning, community participation, poverty alleviation, human and institutional capacity, consumption, population growth and agricultural planning (Whitten et al. 2001). The great challenge of conserving butterfly habitats in South Africa thus not only depends on the level of biological scientific information, but on how that information is presented and linked with management that takes into account socio-economic factors.

\section{Conservation history}

The conservation of butterflies in South Africa has a proud history, but has not been without difficulties. Henning (1997) gave an outline of major events that enhanced the conservation of butterflies in South Africa. Four of sixteen butterflies that were added to Schedule 2 of the list of protected wild animals in the Cape Province in 1976, due to motivation by C.G.C Dickson, were Chrysoritis species. These were Chrysoritis endymion, Chrysoritis lyncurium, Chrysoritis nigricans and Chrysoritis rileyi. In the northern areas (the old Transvaal), Chrysoritis aureus was added to the protected wild animal list of Transvaal (now known as four provinces: Gauteng, Mpumalanga, Northern Province and North West) under Ordinance 12 of 1983 , since the type locality had been the only known locality of the butterfly for a long time (De Wet 1987). Unfortunately, all the members of the genus Charaxes were also put on the protected wild animal list at the same time. Many of the Charaxes species are very widespread in the savanna and had not been under any threat at any stage. The placement of all the Charaxes species on the protected list therefore compromised the validity of the above Ordinance and did not help to highlight the importance of protecting Chrysoritis aureus. This showed that it is essential that effective consultation with stakeholders should take place before laws are instated. An NGO that has played a very important role in Lepidoptera conservation to date is the Lepidopterists' Society of Southern Africa that was founded in 1983. One of the aims of the Lepidopterists' Society of Africa (previously of Southern Africa) is to promote the conservation of Lepidoptera in the Afrotropical region. Although this society consists largely of amateur lepidopterists, major contributions towards butterfly (insect) conservation in Africa was initiated by its members. The proclamation of the Ruimsig Entomological Reserve for the threatened Aloeides dentatis subsp. dentatis by the Roodepoort City Council in 1985 the first of its kind in Africa - was a landmark for conservation of localised butterflies in Africa. This event draw attention to the urgency and significance of conserving the vulnerable habitats of localised myrmecophilous butterflies. No issue on insect conservation in Africa entered the realm of government policies and public perceptions to such an extent as the saga that led to the protection of the last known locality of Orachrysops niobe (the Brenton Blue butterfly). The "Brenton Blue Saga" has been described in detail by Steenkamp \& Stein (1999). The Minister of Environmental Affairs and Tourism invoked Section 31A of the Environment Conservation Act, 73 of 1989, whereby a landowner was deprived of developing his property in order to conserve the habitat of the Brenton Blue butterfly (Orachrysops niobe) (Steenkamp \& Stein 1999). Any similar conflict to follow will be able to deal with the matter at hand with far 
firmer legislative and procedural foundations at their disposal (Steenkamp \& Stein 1999).

The Red Data Book of butterflies (Henning \& Henning 1989; Henning \& Henning 1995) was yet another major achievement for insect conservation in Africa. Again, without the endeavours of many professional entomologists but many more of the amateur fraternity over the years, the Red Data Book would have remained only a dream. Table 2 gives a summary of the Chrysoritis species that were regarded as Red data species. A number of synonymies are present for formerly Red Data categorised butterflies (Table 2), which confirms that the taxonomy of the Chrysoritis genus, should be more satisfactory resolved, especially if the aim was to compile species lists for red listing.

The red listing of some of the Chrysoritis species needs to be reviewed to an extent that one can follow conservation progress clearly. The latest categories by the IUCN (2001) - adopted in 1994 - will help to standardise and establish a red listing, especially in the case of Chrysoritis, for those species that were previously in the rare and intermediate categories of the Red Data Book. A review falls beyond the scope of this paper but a few examples are mentioned to illustrate some practical aspects of such a review. In the case of Chrysoritis dicksoni one is sure at present that the butterfly is in the process of vanishing if proper conservation strategies were not implemented in the near future (this butterfly should be entered in the critically endangered category). As mentioned earlier in the paper, the numbers of Chrysoritis aureus are also dwindling (it is almost absent at its type locality) but it seems that conservation efforts may be in time to save the butterfly, and especially much of its metapopulation structure, from the impact of urbanisation. Localised Chrysoritis species in remote farm areas such as those in the Sutherland area (Roggeveld escarpment) in the Northern Cape should probably be transferred from the old rare to the new least concern category or be abandoned from the red list if more localities become known (see IUCN 2001).
Monitoring of these localised butterflies should be in place for such species that could become threatened in a relatively short time by alien vegetation and perhaps also global climate changes. According to the most recent IUCN categories, the red listing is being addressed at present. Blue lists of threatened species may later be introduced to motivate people in their conservation efforts (Gigon et al. 2000). Such lists could be of special value to the conservation of Chrysoritis species.

\section{Conservation, collecting and the law}

The legal regime for the conservation and sustainable use of biodiversity is centred on the 1992 Convention on Biological Diversity. The primary focus of the 1992 Convention is the conservation of biodiversity and equitable distribution of its benefits (Glazewski 2000). The inclusion of an environmental clause, 108 of 1996, in the Bill of Rights chapter of the South African Constitution was a major step in the development of substantial environmental law in South Africa (Glazewski 2000). Not only does the environmental clause constitute statements that clearly promotes conservation, these have also been further concretised in the set of environmental management principles underpinning the National Environmental Management Act, 107 of 1998 (NEMA) (Glazewski 2000). In effect, these inclusions in law had and will have a substantial constructive effect on conservation of sensitive habitats and endangered species in South Africa in future. Some species, such as the red listed species, are protected in various ways in the schedules of ordinances of the provinces in South Africa. Such a system is thought to be regionally adaptable to local needs and ecological circumstances (Glazewski 2000). The four nature conservation ordinances that applied to the former four provinces in South Africa, still apply in many cases to the nine provinces of South Africa (see Glazewski 2000). In practice the above necessitates a constant vigilance by the scientific community to monitor the status of species in each province and thus 
demands a sophisticated administrative and technical infrastructure that many of the under-resourced provinces lack (Glazewksi 2000).

The particular challenges of the monitoring of insect species in the vast South African countryside should be appreciated here. In the case of Chrysoritis (which already belongs to a well-known insect group, the butterflies) neither the scientific community nor the conservation authorities has the manpower and funds to monitor the status of the rare species regularly enough to follow progress or decline sufficiently, not even in nature reserves or national parks. For perspective, note that for many of the nature reserves and national parks in South Africa a species list of butterflies (the most baseline information) does not exist. To complicate matters, some of the Chrysoritis species, such as Chrysoritis endymion, are not seen every year despite visits by lepidopterists at the right time of the year. To identify the more rare Chrysoritis species in the field and even in the laboratory, takes a specialist - a skill that would be nearly impossible in most cases for the already overburdened conservation officials to acquire. One possible solution is to involve the insect collectors (in this case the butterfly collector) in the monitoring as well as the location of the insect (butterfly) habitats.

An important issue, inevitably touched on in many of the above discussions regarding legislation that seriously needs to be addressed, is the role of the butterfly collector. Therefore, this is an area that needs urgent attention. New (1997) stated that it is vital to sustain the symbiosis and co-operation between professional scientists and amateurs, as efficient assessment of many butterfly populations can only be enhanced in this way. Armstrong (1998) gives a valuable perspective on the importance of the contribution of the amateur lepidopterist but also the vital role of conservation authorities. The information that could be made available by bona fide amateur butterfly collectors for properly conserving butterflies and ecosystems by conservation authorities have been very valuable in the past. This is relevant for the Chrysoritis species, e.g., the new localities that have been found for Chrysoritis dicksoni. In South Africa, there is no evidence of any butterfly populations being destroyed by collecting. It is recommended that collection take place strictly for scientific purposes, such as for SEM studies, at any of the known localities of Chrysoritis dicksoni. Collection of more specimens at these localities, for purposes of expanding collections, will be of no value. The same applies to other localised butterflies from the genus Orachrysops (Orachrysops niobe and Orachrysops ariadne). It is not certain whether the conservation legislation would be better served by a national body than legislation by the different provinces or at least a streamlined coordination from a national level. The issuing of permits should be streamlined and a more pragmatic approach should be adapted for facilitating collectors who wants to make a contribution towards the knowledge on Lepidoptera. As stated in Glazewski (2000): "much remains to be done particularly as regards the co-ordination of the administration of a diffuse set of laws".

There remains, as pointed out by Steenkamp \& Stein (1999), a number of strategic issues with which the conservation establishment will have to deal if they want to ensure ongoing civil society participation in environmental decision-making. The conservation efforts in connection with Aloeides dentatis and Orachrysops niobe have led to an awareness that will possibly enhance the conservation of all the localised lycaenid butterflies in South Africa. Personal experience is that since the application of the law in the case of Orachrysops niobe, people, including landowners and developers, have been much more aware of possible red listed butterfly species and possible unique habitats. To what extent, remains to be seen. Biodiversity and the quality of such data in environmental impact assessments deserve attention beyond the scope of this overview. Another key problem in saving threatened butterfly species is the notion that the habitat must be the last known habitat before the protection really becomes urgent. Conservation of but- 
terflies (and other insects) should be seen in a much wider integrated sense of conserving metapopulations.

\section{Education and awareness}

Without education and public awareness the loss of touch with the environment, in which most modern and developing societies seem to find themselves, would continue. Conservation in South Africa has shifted in recent years from a protectionist approach towards one that involves the community in conservation (Wynberg 2002). Butterflies such as Chrysoritis should be taken to the community. Education, and use of a more indigenous curriculum in schools is needed to appreciate the existence of biological intricacies such as the ecology of Chrysoritis species in Africa. Nature reserves such as the Alice Glockner Nature Reserve and Suikerbosrand Nature Reserve provide excellent opportunities for such educational programmes and should be managed as such. In the case of Chrysoritis aureus, the efforts of Gauteng Nature Conservation to enhance co-operation in research and conservation have been most valuable. Hopefully, these initiatives will prove valuable in a country that has many socio-economic issues that have to be addressed urgently. Encouraging is that the above conservation efforts are directed at the 'small things' in natural veld, a possible source for ecotourism and education - very poorly exploited up to now. Synecological studies, which are conducted to conserve the butterfly, could also benefit the development of the Alice Glockner Nature Reserve as a whole, addressing other aspects of biodiversity apart from butterfly conservation. At present the management of urbanisation close to the Alice Glockner Nature Reserve deserves further attention, especially with regard to community involvement and public awareness.

The involvement of the younger generation (school learners and students), if only to start collecting butterflies in a back yard, may mean much more to science in the end, if it results, for instance, in new locality records of butterflies - or even new scientists - than no involvement caused by too strict legislation. In the end such involvement will enhance the conservation of butterflies (or other insects) rather than decrease the chances of their survival. A fear that the layman collector might collect butterflies such as Chrysoritis aureus and destroy colonies of the butterfly is probably overrated for the following three reasons. The butterfly is easy to recognise by anybody with a good reference guide and reasonable experience of Lepidoptera, but unlikely to be found by a novice. Furthermore, the confirmed localities are clearly protected in nature reserves, especially the established Alice Glockner Nature Reserve. Any lepidopterist that would want to survey butterflies in such a nature reserve would have to submit a research proposal (which always foreruns the issuing of any permit), stating that they know about the butterfly and will avoid to collect any of these.

\section{Integrating science, environmental manage- ment, policies, law and education}

The integration of the efforts of scientists, the public sector and the government can only be successful if proper communication takes place and therefore proper forums are available for such communication. The journal Metamorphosis (Journal of the Lepidopterists' Society of Southern Africa) has acted as a forum for debate in the past (e.g. De Wet 1990; Vlok 1993; Woodhall 1994) between the lepidopterists and conservation authorities, with regard to the issue of collecting butterflies and approaches in conservation. The discussions between conservation authorities, researchers and other stakeholders on the issuing of permits for collecting insects as well as the law governing the protection of material collected in South Africa, was initiated at the 13th Congress of the Entomological Society of Southern Africa in Pietermaritzburg were encouraging. Another important event that coincided with the 13th Congress was a symposium on Arthropod diversity and conservation in Southern Africa, so that emphasis was also 
on insect conservation and not only those insects of economic agricultural importance (not that it is not all part of environmental management).

\section{Conclusions}

Since the genus contains a number of localised populations and subpopulations of significant biological and aesthetic value, Chrysoritis genus should be seen as endemic as a whole. It is clear that the genus contains bioindicators that should be verified according to the categories set out by McGeoch (1998). Since the butterfly populations of Chrysoritis tend to be localised, it is especially their role as ecological indicators and biodiversity indicators that are worth considering. The scales within which the Chrysoritis species could be used are important. On a larger geographical scale their dwindling number of populations is certainly indicative of anthropogenic pressures on sensitive habitats.

Despite the fact that butterflies are such a relatively well studied group of insects in South Africa, limitations in our knowledge still exist even on the taxonomic and distributional level. Being a relatively well-known invertebrate group, the taxonomy of butterflies such as Chrysoritis has reached a state where revisions could easily result in a number of unnecessary names. It is recommended that the relationships between the entities are carefully analysed in such a manner that the work can be traced and repeated. More specific distribution records will be a valuable aid for resolving the taxonomy and responses of such habitat-sensitive butterflies to environmental changes. Legislation should facilitate rather than limit the valuable role that the amateur may play to contribute in the gathering of distribution records. In turn, the amateur lepidopterists should adapt and make an effort to include unknown localities, apart from monitoring butterflies at their well-known localities. This information should also be readily available to conservation authorities. A system in which the amateur fraternity also takes responsibility - aided by codes of conduct-to maintain optimal co-operation between the Government and the NGO should be in place. Species such as Chrysoritis dicksoni should be protected by law (also from collecting) at their known and conserved localities.

Distribution records are not in any atlas format, a fact which limits our understanding of especially a genus such as Chrysoritis that contains a number of highly localised and endemic butterflies. A Southern African butterfly atlas would be appropriate and in fact a necessity, since it would enhance the understanding of the biogeography of a group of butterflies that might be good bioindicators on a large geographical scale. It is to be hoped that butterflies, that seems to be ideal for atlas work, would be included as part of the Biodiversity and Conservation for South African Invertebrates initiative (Hamer \& Underhill 2001) or any other similar initiatives.

The red listing of localised (myrmecophilous) butterflies such as the Chrysoritis is in need of urgent review in the light of the most recent IUCN categories (IUCN 2001) that were adopted in 1994. The environmental management priorities are linked to applied ecology, but the infrastructure to build the necessary bridges in practice, is often lacking. A sound ecosystem approach in conservation biology lies in the intersection between ecological, socio-economic and institutional perspectives (Meffe \& Carol 1997). This cannot be more true for the conservation of Chrysoritis species. It is therefore clear that the prosperity of Chrysoritis species not only depends on our understanding of its interactions in nature in the context of communities, but also of our human interactions as scientists, NGO members, policymakers, law makers, educators, environmentalists and citizens in whatever capacityespecially when it comes to the integration of our efforts. The above that the organisations/institutions involved with conservation strategies, the monitoring ideals and the legislation, should appreciate the challenges particular to insect conservation. 


\section{Acknowledgements}

The comments of three anonymous reviewers greatly improved the manuscript.

\section{References}

ACOcKs, J.P.H. 1975. Veld types of South Africa. 2nd ed. Memoirs of the botanical survey of South Africa No. 40.

ACOCKS, J.P.H. 1988. Veld types of South Africa. 3rd ed. Memoirs of the botanical Survey of South Africa 57: 1-146.

ARMSTrong, A.J. 1998. Letters to the editor. Metamorphosis 9(3): 141-143.

BAYER, M.B. 1999. Haworthia revisited: a revision of the genus. Hatfield: Umdaus Press.

BREDENKAMP, G.J. \& N. van RoOYEN. 1996. Rocky Highveld grassland. P. 39. In: Low, A.B. \& A.G. Rebelo (eds.). Vegetation of South Africa, Lesotho and Swaziland. Pretoria: Department of Environmental Affairs \& Tourism.

Claassens, A.J.M. 1994. Recent observations on Lepidoptera. Metamorphosis 5(2): 53-54.

Claassens, A.J.M. 2000. The butterflies of the Cape Peninsula: a comprehensive guide. Cape Town: Tafelberg.

Clark, G.C. \& Dickson, C.G.C. 1971. Life histories of the South African lycaenid butterflies. Cape Town: Purnell.

CotTrell, C.B. 1985. The absence of coevolutionary associations with Capensis floral element plants in the larval/plant relationships of South Western Cape butterflies. Pp. 115-124. In: VRBA, E.S. (ed.). Species and speciation. Transvaal Museum Monograph No. 4.

Cowling, R.M., D.M. Richardson \& S.M. Pierce (eds.). 1997. Vegetation of Southern Africa. Cambridge: University Press.

De Wet, J.I. 1987. Die bewaring van skoenlappers van die genus Charaxes en van Erikssonia acraeina in die Transvaal. Proceedings of the first Lepidoptera Conservation Symposium, Roodepoort: Lepidopterists' Society of Southern Africa: 5-7.

DE Wet, J.I. 1990. Surveys of Lepidoptera on provincial nature reserves. Metamorphosis 27: 8-10.

Duke, N., J. Saunders \& C. Saunders. 1999. A checklist of insects of Swaziland. Mbabane: The Conservation Trust of Swaziland and the Natural History Society of Swaziland.

Gigon, A., R. Langenauer, C. Meier \& B. NieverGELT. 2000. Blue lists of threatened species with stabilised or increasing abundance: a new instrument for conservation. Conservation Biology 14(2): 402-413.
Glazewski, J. 2000. Environmental law in South Africa. Durban: Butterworths.

Granger, J.E. \& G.J. BREDENKAMP. 1996. Alti mountain grassland. P. 49. In: Low, A.B. \& A.G. Rebelo (eds.). Vegetation of South Africa, Lesotho and Swaziland. Pretoria: Department of Environmental Affairs \& Tourism.

HAMER, M.L. \& L. UnDERHILL. 2001. Improved biodiversity conservation through survey, atlasing, and conservation evaluation of invertebrates in South Africa. Proceedings of the 13th Entomological Congress of the Entomological Society of Southern Africa.

HeAth, A. 1997a. A review of African genera of the tribe Aphnaeini (Lepidoptera: Lycaenidae). Metamorphosis: occasional supplement 2: 1-60.

Heath, A. 1997b. Myrmecophily and the male genitalia of African Lycaenidae: a preliminary discussion. Metamorphosis: occasional supplement 3: 89-97.

Heath, A. 2001. New synonymies and taxonomic notes on the genus Chrysoritis (Butler) (Lepidoptera: Lycaenidae). Metamorphosis 12(3): 85-98.

HENNING, G.A. 1986a. Research at Suikerbosrand Nature Reserve: 7 Sept. Unpublished report for the Transvaal Nature Conservation Division: Lepidopterists' Society of Southern Africa.

HenNing, G.A. 1986b. Research at Suikerbosrand Nature Reserve: 2 Dec. Unpublished report for the Transvaal Nature Conservation Division: Lepidopterists' Society of Southern Africa.

HENNING, G.A. 1987. Research at Suikerbosrand Nature Reserve: 1st quarter. Unpublished report for the Transvaal Nature Conservation Division: Lepidopterists' Society of Southern Africa.

HENNING, G.A. 1997. Butterfly conservation in South Africa. Metamorphosis: occasional supplement 3: $120-128$.

HENNING, G.A. \& S.F. HENNING. 1995. Updating the status of South African red data butterfly species. Metamorphosis 6(3): 96-98.

HenNing, S.F. \& G.A. Henning. 1989. South African red data book: butterflies. Pretoria: Council for Scientific and Industrial Research, National Scientific Programmes Unit. (South African National Scientific Programmes report; no. 158.)

IUCN. 2001. IUCN Red List Categories and Criteria: Version 3.1. Gland: IUCN Species Survival Commission.

Keller, W.C.F., C.R. Amodio \& S. Stänz. 1997. A preliminary and annotated list of Lepidoptera butterflies (Papilionoidea) and moths (Hesperiidae, Sphingidae, Saturniidae), recorded from the Kingdom of Lesotho, South Africa. Metamorphosis 8(3): 109-130.

Kloppers, J., \& G. VAN SON. 1978. Butterflies of the Kruger National Park. Pretoria : National Parks Board. 
Kohm, K., P.D. Boersma, G.K. Meffe \& R. Noss. 2000. Editorial: Putting science into practice and practice into science. Conservation Biology 14 (3): 593-594.

Low, A.B. \& A.G. ReBelo. (eds.). 1996. Vegetation of South Africa, Lesotho and Swaziland. Pretoria: Department of Environmental Affairs \& Tourism.

McGeOCH, M.A. 1998. The selection, testing and application of terrestrial insects as bioindicators. Biological Reviews 73(1): 181-201.

McGEOCH, M.A. 2002. Insect conservation in South Africa: an overview. African Entomology 10(1): $1-10$.

Meffe, G.K. \& C.R. Carol. 1997. Principles of conservation biology. Sunderland: Sinauer.

NEw, T.R. 1997. Butterfly conservation. Melbourne: Oxford University Press.

O’Connor, T.G. \& G.J. BredenKamP. 1997. Grassland. Pp. 215-257. In: Cowling, R.M., Richardson, D.M. \& Pierce, S.M. (Eds.) 1997. Vegetation of Southern Africa. Cambridge: University Press.

Owen-Johnston, N.K. 1991. Thoughts and observations on the genus Poecilmitis Butler (Lepidoptera: Lycaenidae) in the Transvaal. Metamorphosis 2(3): 49-50.

Pringle, E.L., G.A. Henning \& J.B. Ball. (eds.). 1994. Pennington's butterflies of Southern Africa. Cape Town: Struik.

PRYKe, S.R. \& M.J. SAMWAYS. 2001. Width of grassland linkages for the conservation of butterflies in South African afforested areas. Biological Conservation 101: 85-96.

Rand, D.B., A. Heath, T. Suderman \& N.E. Pierce. 2000. Phylogeny and life history evolution of the genus Chrysoritis within the Aphnaeini (Lepidoptera: Lycaenidae), inferred from mitochondrial cytochrome oxidase I sequences. Molecular Phylogenetics and Evolution 17: 85-96.

Roos, P. \& G.A. HenNING. 2000. The Heidelberg Copper Butterfly. African Wildlife 54(2): 24-27.

Rutherford, M.C. \& R.H. Westfall. 1994. Biomes of southern Africa: an objective categorisation. Memoirs of the Botanical Survey of South Africa, No 63.

SAMWAYS, M.J. 1993. Threatened Lycaenidae of South Africa. Pp. 62-69. In: NEW, T.R. (ed.).
Conservation biology of Lycaenidae (butterflies). Gland: IUCN Species Survival Commission. (Occasional paper of the IUCN Species Survival Commission; no. 8.)

SAMWAYS, M.J. 1994. Insect conservation biology. London: Chapman \& Hall.

Steenkamp, C. \& Stein, R. 1999. The Brenton blue saga: a case study of South African biodiversity conservation. Parkview: EWT.

Terblanche, R.F. 1991. Trip to Golden Gate in the Orange Free State. Metamorphosis 2(3): 46-48.

Terblanche, R.F., G.F. Smith \& J.D. Theunissen. 1993. Did Scott typify names in Haworthia (Asphodelaceae: Alooideae)? Taxon 42(1) : 9195.

Terblanche, R.F., T.L. Morgenthal \& S.S. CiLliers. 2003. The vegetation of three localities of the threatened butterfly species Chrysoritis aureus (Lepidoptera: Lycaenidae). Koedoe 46(1): 73-90.

Terblanche, R.F. \& J.C. TAYlor. 2000. Notes on the butterflies of Witsand - a unique terrestrial island in the Northern Cape Province, South Africa-with special reference to two red data book butterfly species. Metamorphosis 11(3): 122-131.

VÁri, L., D.M. Kroon \& M. KRÜGER. M. 2002. Classification and checklist of the species of Lepidoptera recorded in Southern Africa. Chatswood: Simple Solutions.

VLOK, J. 1993. In defence of Cape nature conservation - a reply to Steve Woodhall. Metamorphosis 4(4): 180-181.

Whitten, T., D. Holmes \& K. Mackinnon. 2001. Conservation biology: a displacement behaviour for academia? Conservation Biology 15(1): 1-3.

WoodhaLl, S.E. 1994. Cape nature conservation - a reply to J. Vlok. Metamorphosis 5(2): 77-78.

WoOdHALL, S.E. 1996. The plight of Poecilmitis lyncurium (Trimen, 1868). Metamorphosis 7(1):34-36.

WyNBERG, R. 2002. A decade of biodiversity conservation and use in Africa: tracking progress from the Rio Earth Summit to the Johannesburg World Summit on sustainable development. South African Journal of Science 98: 233-243. 